\title{
DIALOGUE: TOWARD SUPERIOR STAKEHOLDER THEORY
}

\author{
Bradley R. Agle, Thomas Donaldson, R. Edward Freeman, \\ Michael C. Jensen, Ronald K. Mitchell, and Donna J. Wood
}

\begin{abstract}
A quick look at what is happening in the corporate world makes it clear that the stakeholder idea is alive, well, and flourishing; and the question now is not "if" but "how" stakeholder theory will meet the challenges of its success. Does stakeholder theory's "arrival" mean continued dynamism, refinement, and relevance, or stasis? How will superior stakeholder theory continue to develop? In light of these and related questions, the authors of these essays conducted an ongoing dialogue on the current state and future of stakeholder thinking. Beginning with a review of research and theory that has developed since the major stakeholder theorizing efforts of the 1990s, the authors individually offer their perspectives on the key issues relevant today to stakeholder thinking, and to suggest possible approaches that might lead toward and enable the continuing development of superior stakeholder theory.
\end{abstract}

Editor's note: The 2007 national meeting of the Academy of Management, held in Philadelphia, featured an "All-Academy" symposium on the future of stakeholder theorizing in business. In order to make the varying perspectives represented in that symposium available to a larger audience, the symposium participants have provided these short, thought-provoking essays, which Business Ethics Quarterly offers as a dialogue on the current and future state of stakeholder perspectives. Symposium organizer Bradley Agle and Ronald Mitchell provide an introduction to the issues and perspectives under consideration. These comments are followed by essays by Donna Wood, R. Edward Freeman, Michael Jensen, Thomas Donaldson, and Ronald Mitchell, with concluding comments by Bradley Agle and Ronald Mitchell.

\section{Introduction: Recent Research AND NEW Questions}

\section{Bradley R. Agle and Ronald K. Mitchell}

$\mathrm{T}$ The stakeholder idea is alive, well, and flourishing. The relevant question now is not "if," but "how" stakeholder theory will meet the challenges of its success. A recent random sample of websites (looking at statements about mission, vision, philosophy, values, etc.) of 100 companies drawn from the Fortune 500 found that only ten companies espoused the "pure stockholder" focus of value maximization for stockholders, 
and twenty-two espoused a "legally and ethically bounded" stockholder focus, while sixty-four embraced approaches to "maximize the well-being of all stakeholders," and yet another two aimed at solving "social problems while making a fair profit" (Agle $\&$ Agle, 2007). So the question now is whether stakeholder theory's "arrival" means continued dynamism, refinement, and relevance, or stasis. Will superior stakeholder theory continue to develop, and if so, how? In this introduction to the following essays adapted from the 2007 Academy of Management symposium on "superior stakeholder theory," we situate the overall symposium within the stakeholder literature that has developed since the major stakeholder theory efforts of the 1990s, and offer a general introduction to the dialogue. Following the essays by each symposium panelist, we will offer some concluding comments regarding possible avenues that might lead toward and enable the continuing development of superior stakeholder theory.

In our preparatory review of recent stakeholder-based literature, we (the symposium participants) noticed three strands in the works reviewed: (1) works concerning the basic debate (stakeholder vs. stockholder), (2) works that focus on the instrumental development of stakeholder approaches, and (3) works that generate new questions in stakeholder theory research. Table 1 presents representative articles from these three strands of recent stakeholder thinking. It was immediately evident to us that the primary objective of the "debate" strand of stakeholder-theory research has been to address assertions about the relative contributions or privileges of stakeholders and stockholders. Table 1 provides examples of several articles that have taken on this task with rigor and thoughtfulness (e.g., Freeman, Wicks \& Parmer, 2004). We also note a sub-theme within the debate literature, whereby authors have worked to advance the theoretical specificity and clarity of the two theories in juxtaposition (e.g., Phillips, Freeman, \& Wicks, 2003; Smith, 2003). In the instrumental development strand of recent research, we note the underlying premise being considered: if stakeholder sensitive management is better, stockholders should do better (e.g., Berman, Wicks, Kotha, \& Jones, 1999; Hillman \& Keim, 2001). A primary and consistent finding within this strand of research - that with or without a stakeholder focus, corporate performance is very much the same-suggests room for stakeholder focused management that does no harm to stockholder interests while also benefiting a larger constituency (e.g., Moneva, Rivera-Lirio \& Munoz-Torres, 2007). In the third research-agenda-focused strand of recent work, four areas of new inquiry include: (a) how the normative underpinnings of stakeholder theory can help the business ethics field by providing ethical insights useful in the processes of managing; (b) how alternatives to the stakeholder/stockholder debate can provide normative reasons for stakeholder-responsive action where the market fails society (e.g., a market failures/government response approach in circumstances wherein the pursuit of private interest does not lead to an efficient use of society's resources or a fair distribution of society's goods (Heath, 2006; cf. Jensen's comments below)); (c) how stakeholder theory can provide ideas and frameworks that managers can use to run organizations better; and (d) how better theory and methods-whether borrowed from other fields or indigenous to the world of stakeholder scholars-can serve stakeholder theory development. 
Table 1. Superior Stakeholder Theoery: Some Contributions 1999-2007 (arranged chronologically by major theme)

\begin{tabular}{|c|c|c|c|}
\hline $\begin{array}{l}\text { Normative Stakeholder } \\
\text { vs Stockholder Theory }\end{array}$ & & & \\
\hline Author(s) & Year & Outlet & Some Key Ideas \\
\hline Marens \& Wicks & 1999 & BEQ & $\begin{array}{l}\text { "This fiduciary duty requires the exercise of care, } \\
\text { loyalty, and honesty with regard to the financial } \\
\text { interests of stockholders. Such obligations do not } \\
\text { conflict with the normative goals of stakeholder } \\
\text { theory." }\end{array}$ \\
\hline Palmer & 1999 & BEQ & $\begin{array}{l}\text { "First, I show that utilitarian considerations } \\
\text { clearly favor the stakeholder theory. I then argue } \\
\text { that though Hasnas rightly accents the basic deon- } \\
\text { tological constraint at the core of the stockholder } \\
\text { theory, he is wrong to think that acknowledging } \\
\text { such a constraint necessarily counts against the } \\
\text { stakeholder theory." }\end{array}$ \\
\hline Hendry & 2001 & BEQ & $\begin{array}{l}\text { "The paper identifies three distinct kinds of } \\
\text { normative stakeholder theory and three different } \\
\text { levels of claim that can be made by such theories, } \\
\text { and uses this classification to argue that stake- } \\
\text { holder theorists have consistently pitched their } \\
\text { sights too high or too low to engage effectively } \\
\text { with the rival shareholder theory." }\end{array}$ \\
\hline Jensen & 2002 & BEQ & $\begin{array}{l}\text { "Since it is logically impossible to maximize in } \\
\text { more than one dimension, purposeful behavior } \\
\text { requires a single valued objective function. Two } \\
\text { hundred years of work in economics and finance } \\
\text { implies that in the absence of externalities and } \\
\text { monopoly (and when all goods are priced), so- } \\
\text { cial welfare is maximized when each firm in an } \\
\text { economy maximizes its total market value." }\end{array}$ \\
\hline Marcoux & 2003 & BEQ & $\begin{array}{l}\text { "I advance an argument that seeks to demonstrate } \\
\text { both the special moral status of shareholders in } \\
\text { a firm and the concomitant moral inadequacy of } \\
\text { stakeholder theory." }\end{array}$ \\
\hline $\begin{array}{l}\text { Phillips, Freeman \& } \\
\text { Wicks }\end{array}$ & 2003 & BEQ & $\begin{array}{l}\text { "The goal of the current paper is like that of a } \\
\text { controlled burn that clears away some of the } \\
\text { underbrush of misinterpretation in the hope of } \\
\text { denying easy fuel to the critical conflagration that } \\
\text { would raze the theory." }\end{array}$ \\
\hline Smith & 2003 & $\begin{array}{l}\text { Sloan Mgt } \\
\text { Review }\end{array}$ & $\begin{array}{l}\text { "Should companies seek only to maximize share- } \\
\text { holder value or strive to serve the often conflicting } \\
\text { interests of all stakeholders? Guidance can be } \\
\text { found in exploring exactly what each theory does } \\
\text { and doesn't say." }\end{array}$ \\
\hline $\begin{array}{l}\text { Freeman, Wicks \& } \\
\text { Parmer }\end{array}$ & 2004 & Org Science & $\begin{array}{l}\text { "This paper offers a response to Sundaram } \\
\text { and Inkpen's article 'The Corporate Objective } \\
\text { Revisited' by clarifying misconceptions about } \\
\text { stakeholder theory and concluding truth and } \\
\text { freedom are best served by seeing business and } \\
\text { ethics combined." }\end{array}$ \\
\hline
\end{tabular}




\begin{tabular}{|c|c|c|c|}
\hline $\begin{array}{l}\text { Velamuri \& } \\
\text { Venkataraman }\end{array}$ & 2005 & JBE & $\begin{array}{l}\text { "The normative foundations of the investor cen- } \\
\text { tered model of corporate governance, represented } \\
\text { in mainstream economics by the nexus-of-contract } \\
\text { view of the firm, have come under attack, mainly } \\
\text { from the proponents of normative stakeholder } \\
\text { theory. We argue that the nexus of contracts view } \\
\text { is static and limited due to its assumption of price- } \\
\text { output certainty." }\end{array}$ \\
\hline Heath & 2006 & BEQ & $\begin{array}{l}\text { "The question posed in this paper is whether the } \\
\text { stakeholder paradigm represents the most fruitful } \\
\text { way of articulating the moral problems that arise } \\
\text { in business. By way of contrast, I outline two other } \\
\text { possible approaches to business ethics: one, a } \\
\text { more minimal conception, anchored in the notion } \\
\text { of a fiduciary obligation toward shareholders; and } \\
\text { the other, a broader conception, focused on the } \\
\text { concept of market failure." }\end{array}$ \\
\hline \multicolumn{4}{|l|}{$\begin{array}{l}\text { Instrumental } \\
\text { Stakeholder Theory }\end{array}$} \\
\hline $\begin{array}{l}\text { Agle, Mitchell \& } \\
\text { Sonnenfeld }\end{array}$ & 1999 & AMJ & $\begin{array}{l}\text { "We found strong support for the attribute-salience } \\
\text { relationship and some significant relationships } \\
\text { among CEO values, salience, and corporate social } \\
\text { performance but found no support for a salience- } \\
\text { financial performance link." }\end{array}$ \\
\hline $\begin{array}{l}\text { Berman, Wicks, Kotha } \\
\text { \& Jones }\end{array}$ & 1999 & AMJ & $\begin{array}{l}\text { "The results provide support for a strategic stake- } \\
\text { holder management model but no support for an } \\
\text { intrinsic stakeholder commitment model." }\end{array}$ \\
\hline Luoma \& Goodstein & 1999 & AMJ & $\begin{array}{l}\text { "This study examined the relationships between } \\
\text { institutional influences and stakeholder represen- } \\
\text { tation on boards of directors." }\end{array}$ \\
\hline Ogden \& Watson & 1999 & AMJ & $\begin{array}{l}\text { "This study examined a major contention of } \\
\text { stakeholder theory: namely, that a firm can simul- } \\
\text { taneously enhance the interests of its shareholders } \\
\text { and other relevant stakeholders. ... We interpret } \\
\text { this finding as being consistent with stakeholder } \\
\text { theory." }\end{array}$ \\
\hline Hillman \& Keim & 2001 & SMJ & $\begin{array}{l}\text { "We ... find evidence that stakeholder manage- } \\
\text { ment leads to improved shareholder value, while } \\
\text { social issue participation is negatively associated } \\
\text { with shareholder value." }\end{array}$ \\
\hline $\begin{array}{l}\text { Omran, Atrill \& } \\
\text { Pointon }\end{array}$ & 2002 & $\begin{array}{l}\text { Business } \\
\text { Ethics: } \\
\text { A European } \\
\text { Review }\end{array}$ & $\begin{array}{l}\text { "The overall conclusion is that there is no sig- } \\
\text { nificant difference in shareholder returns between } \\
\text { stakeholder-oriented and shareholder-oriented } \\
\text { companies." }\end{array}$ \\
\hline $\begin{array}{l}\text { Bartkus, Glassman \& } \\
\text { McAfee }\end{array}$ & 2006 & EMJ & $\begin{array}{l}\text { "Mission statements that include phrases that refer } \\
\text { to what many may view as the fundamental rules } \\
\text { of business have a significant positive relationship } \\
\text { with financial performance: be concerned with } \\
\text { your employees, be responsible to the society in } \\
\text { which you do business, and emphasize and com- } \\
\text { municate your value system." }\end{array}$ \\
\hline $\begin{array}{l}\text { Moneva, Rivera-Lirio \& } \\
\text { Munoz-Torres }\end{array}$ & 2007 & $\begin{array}{l}\text { Industrial } \\
\text { Management } \\
\text { and Data } \\
\text { Systems }\end{array}$ & $\begin{array}{l}\text { "[T]he main conclusion drawn from the analysis } \\
\text { shows that the financial performance of the sec- } \\
\text { tors or organizations with a greater stakeholder } \\
\text { strategic commitment, is not inferior to that of } \\
\text { the sectors or organizations with a shareholder } \\
\text { approach." }\end{array}$ \\
\hline
\end{tabular}




\begin{tabular}{|c|c|c|c|}
\hline $\begin{array}{l}\text { New Questions: } \\
\text { Further Development } \\
\text { Stakeholder Theory }\end{array}$ & & & \\
\hline Cludts & 1999 & BEQ & $\begin{array}{l}\text { "While we do not challenge the principle of fair- } \\
\text { ness itself, we claim that when this principle is } \\
\text { applied only to those who invest in the corpora- } \\
\text { tion, it cannot serve as the ground for an ethical } \\
\text { stakeholder theory." }\end{array}$ \\
\hline Donaldson & 1999 & AMR & $\begin{array}{l}\text { "The most interesting question in stakeholder } \\
\text { theory today is whether a conceptual glue can be } \\
\text { found that is strong enough to bind the separate } \\
\text { methodological strands of stakeholder theory } \\
\text { into a whole." }\end{array}$ \\
\hline Donaldson \& Dunfee & 1999 & HBS Press & $\begin{array}{l}\text { "Our aim is to extend significantly the application } \\
\text { of social contracts to business.... Business ethics, } \\
\text { we assert, is more a bundle of shared understand- } \\
\text { ings than a set of fixed pronouncements." }\end{array}$ \\
\hline Frooman & 1999 & AMR & $\begin{array}{l}\text { "When seeking to influence firm decision-making, } \\
\text { what types of influence strategies do stakeholders } \\
\text { have available and what determines which type } \\
\text { the stakeholders choose to use?" }\end{array}$ \\
\hline Jones \& Wicks & 1999 & AMR & $\begin{array}{l}\text { "Since neither approach is complete without the } \\
\text { other, we propose a new way of theorizing about } \\
\text { organizations: the development of normatively } \\
\text { and instrumentally sound convergent stakeholder } \\
\text { theory." }\end{array}$ \\
\hline Treviño \& Weaver & 1999 & AMR & $\begin{array}{l}\text { "We disagree with Jones and Wicks' contention } \\
\text { that they have developed a "convergent stake- } \\
\text { holder theory' that moves stakeholder research } \\
\text { toward theoretical integration." }\end{array}$ \\
\hline Scott \& Lane & 2000 & AMR & $\begin{array}{l}\text { "We develop a model of organizational identity } \\
\text { construction that reframes organizational identity } \\
\text { within the broader context of manager-stakeholder } \\
\text { relationships and more effectively integrates } \\
\text { theory on organizational identity and organiza- } \\
\text { tional identification." }\end{array}$ \\
\hline Van Buren & 2001 & BEQ & $\begin{array}{l}\text { "In this essay, I propose that a reconstructed } \\
\text { principle of fairness can be combined with the } \\
\text { idea of consent as outlined in integrative social } \\
\text { contracts (ISCT) to bring about a more normative } \\
\text { stakeholder theory that also has ramifications for } \\
\text { corporate governance." }\end{array}$ \\
\hline Jawahar \& McLaughlin & 2001 & AMR & $\begin{array}{l}\text { "We integrate theory and research from dispa- } \\
\text { rate areas to develop a descriptive stakeholder } \\
\text { theory." }\end{array}$ \\
\hline Kochan \& Rubinstein & 2000 & Org Science & $\begin{array}{l}\text { "The idea that the firm should be accountable not } \\
\text { only to shareholders but also to a broader set of } \\
\text { stakeholders is 'in the air.' But what would such } \\
\text { a firm look like?" }\end{array}$ \\
\hline Post, Preston \& Sachs & 2002 & $\begin{array}{l}\text { Stanford } \\
\text { University } \\
\text { Press }\end{array}$ & $\begin{array}{l}\text { "This book presents a stakeholder view of the } \\
\text { corporation in both theoretical and practical terms. } \\
\text { Its central proposition is that organizational wealth } \\
\text { is created (or destroyed) through a corporation's } \\
\text { interactions with its stakeholders." }\end{array}$ \\
\hline
\end{tabular}




\begin{tabular}{|c|c|c|c|}
\hline Schneider & 2002 & Org Science & $\begin{array}{l}\text { "The stakeholder model of organizational lead- } \\
\text { ership helps to predict leader effectiveness In } \\
\text { organizations characterized by fuzzy organiza- } \\
\text { tional boundaries, flattened hierarchies, and work } \\
\text { relationships sometimes brought about through } \\
\text { contracts instead of employment." }\end{array}$ \\
\hline Wolfe \& Putler & 2002 & Org Science & $\begin{array}{l}\text { "We argue that a powerful implicit assumption } \\
\text { within the stakeholder literature-that priorities } \\
\text { within rolebased stakeholder groups are relatively } \\
\text { homogeneous--blurs our understanding of orga- } \\
\text { nization-stakeholder relationships." }\end{array}$ \\
\hline Phillips & 2003 & Berrett-Kohler & $\begin{array}{l}\text { "[O]bligations of stakeholder fairness create direct } \\
\text { moral (normative) obligations." }\end{array}$ \\
\hline Richards & 2004 & $\begin{array}{l}\text { Journal of } \\
\text { Mass Media } \\
\text { Ethics }\end{array}$ & $\begin{array}{l}\text { "A further concept from business and management } \\
\text { that appears to be directly applicable to the news } \\
\text { media is the notion of stakeholders." }\end{array}$ \\
\hline Hall \& Vrendenburg & 2005 & $\begin{array}{l}\text { Sloan Mgt } \\
\text { Rev }\end{array}$ & $\begin{array}{l}\text { "Stakeholder management-especially that of } \\
\text { secondary stakeholders-is becoming increas- } \\
\text { ingly important in many industries." }\end{array}$ \\
\hline Pajunen & 2006 & $\begin{array}{l}\text { Journal of } \\
\text { Management } \\
\text { Studies }\end{array}$ & $\begin{array}{l}\text { "This paper provides a theory and a historical } \\
\text { case study that show how the most influential } \\
\text { stakeholders can be identified and managed during } \\
\text { an organizational survival." }\end{array}$ \\
\hline Barnet & 2007 & AMR & $\begin{array}{l}\text { "I argue that research on the business case for } \\
\text { corporate social responsibility must account for } \\
\text { the path-dependent nature of firm-stakeholder re- } \\
\text { lations, and I develop the construct of stakeholder } \\
\text { influence capacity to fill this void." }\end{array}$ \\
\hline Vilanova & 2007 & EMJ & $\begin{array}{l}\text { "This paper proposes an alternative theory on the } \\
\text { role of management in corporate governance, the } \\
\text { so-called short term salient stakeholder theory, } \\
\text { and illustrates it with a longitudinal case study } \\
\text { of Eurotunnel." }\end{array}$ \\
\hline
\end{tabular}

This research and theory provided the common foundation for the interaction among the symposium participants. As will be seen in the panelists' remarks, an openness to lively debate and to some disagreement characterized this exchange. Nevertheless, a genuine spirit of building bridges of understanding, and where possible, agreement, for the common good guided the discussion, and we hope this sets the tone for further developments in this area.

Picking up on the stakeholder vs. stockholder debate, Donna Wood first focuses our attention on foundations: the assumptions and justifications for a theory that provides credible alternatives to certain received economic thought. Ed Freeman then asks us to move beyond the well-worn "Friedman vs. Freeman" arguments to look collaboratively and operationally at the pragmatics of better stakeholder theory. Michael Jensen addresses some of these issues by arguing for the compatibility of a superior stakeholder theory, ethics, fair distribution, and good management with long-term value maximization, and in the process considers other relevant issues ranging from the role of government to the non-rationality of much human behavior. Then, placing this debate into a larger context, Tom Donaldson suggests a lens whereby the emergence and influence of the stakeholder idea can be seen-in 
comparison to the Copernican Revolution-to be the Normative Revolution, which preserves valuable ideas from the past, while progressing toward ideas that can add more value in the future. Responding to the need for the instrumental vision of stakeholder utility to be enacted, Ron Mitchell engages in a thought experiment to sketch the outlines of, and the kind of thinking required for, the new-type entity that might result from superior stakeholder theory, which he calls the "joint-stake" company (in contrast to the joint-stock company), focusing specifically on the role of notions and practices of accountability in such a company. Each of their essays—capturing their remarks at the symposium—now follows.

\section{CoRporate Responsibility and StAKEHOLDER TheORY: Challenging the Neoclassical Paradigm}

\section{Donna J. Wood}

Tn January of this year, Nobel-Prize-winning economist George Akerlof gave his Ipresidential address to the American Economic Association. Akerlof called for a new emphasis on sensible, pragmatic economics: "You think about problems in the world," he advised, "and you ask: can government do something about that? At the same time, you maintain your skepticism that government is often inefficient" (Uchetelle, 2007).

There certainly is no shortage of "problems in the world." Globalization has made it very clear that multinational corporations have no master, and it has brought into sharp focus income inequities, dire poverty, human rights abuses, environmental degradation, and so much more (Sen, 1997; Wood, Logsdon, Lewellyn \& Davenport, 2006). In addition, the ascendancy of neoclassical economics into the Anglo-American public policy sphere from the 1970s onward has devastated the ability of government to contain corporate abuse or to ameliorate the desperation of the poor (Phillips, 2006). The evidence is all around us that strict free-market policies work wonderfully well for the rich and powerful, but for many others, life has become harder (Ehrenreich, 2001). It has also become clear, as cognitive linguist George Lakoff (1996) has masterfully laid out, that Chicago School neoclassical economics is a socio-political agenda based upon values that emphasize self-reliance over community health, discipline over nurturance, and suffering consequences over creating opportunities. In effect, this worldview is a modern-day return to social Darwinism (Hofstadter, 1944).

In his AEA presidential address, Akerlof pointed to some false assumptions upon which neoclassical economic theory is based. In particular he mentioned people's frequent tendency to behave "irrationally," in the narrow sense of not serving economic self-interests, and he is now studying the other norms and values that undergird human behavior (Uchetelle, 2007). This idea, of course, is not news to philosophers and many social scientists. And there are other untenable assumptions that must be corrected. Michael Jensen encapsulated many of these 
"common-wisdom" assumptions in finance and economics when he wrote: "Since it is logically impossible to maximize in more than one dimension, purposeful behavior requires a single valued objective function. Two hundred years of work in economics and finance implies that in the absence of externalities and monopoly (and when all goods are priced), social welfare is maximized when each firm in an economy maximizes its total market value" (Jensen, 2002).

Here are the untenable assumptions built into this concise statement, at least insofar as it is applied to any actual economy:

1. Rational actors try to maximize their self-interest, which is defined in narrow economic terms.

2. "Maximizing" necessarily involves limited resources that cannot be deployed in multiple directions without loss.

3. Purposeful behavior is maximizing behavior.

4. Externalities are absent.

5. Monopoly is absent.

6. All goods are priced.

7. Social welfare equals efficiency.

8. A firm's market value is its total value.

Mathematical modeling requires assumptions like these, but such assumptions are empirically unsupported-if you consider evidence outside the narrow confines of finance and economics-and theoretically destructive. We know too much about human and organizational irrationality, and satisficing to meet multiple goals (Egidi \& Marris, 1995); about agency, incentive, and control problems (Mitnick, 1980); about the empirical impossibility of "maximizing" in the face of limited, asymmetrical, and often distorted knowledge (Arrow, 1984); and about the presence of economic externalities and monopoly and the fact that not all goods are priced (Stone, 1982). We know that efficiency in resource allocation is only one desirable societal objective; others include fair access to and fair distribution of society's benefits and burdens, along with the preservation of individual rights and of commonly shared resources. We know about the value of firms as community members, knowledge creators, and political actors. In short, we know too much about the institutional role of business in society to be persuaded by arguments about the glories of unfettered free markets with actors solely in pursuit of maximizing their economic self-interest. Although there are many beneficial consequences of the pursuit of self-interest, there can also be toxic consequences if business's institutional role is ignored.

Institutions do not exist to serve their own purposes, but rather to serve the needs of societies and their peoples. Business, like all other societal institutions (including the family, religion, education, government, etc.), serves vital functions but is never completely free to act as an independent entity. All societies use social control mechanisms to govern people, organizations, and institutions-these mechanisms include law, government regulation, economic sanctions, organizational incentives, moral suasion, interpersonal behaviors, and the individual internalization of rules 
and norms. A company's right to pollute a commons or mislabel goods or mislead shareholders ends short of causing harm to the relevant stakeholders. Society's social control mechanisms help to ensure that such rights are not violated and, when they are, that fair compensation and retribution are forthcoming. Social control mechanisms help to ensure that institutions function effectively, and that commons areas are preserved for the benefit of all. They are a necessary antidote to the toxic effects of the pursuit of economic self-interest, and they address several of the false assumptions built into neoclassical economics-in particular, assumptions 4, 5, 6, and 7 listed above.

Business and society research and theory—including stakeholder theorizing-has typically been focused on community, nurturance, opportunities, and avoiding harms; its finest articulations emphasize human rights, dignity, and justice, and the need for corporations to contribute to such desirable outcomes. The concept of corporate social responsibility came about as a way to express an expectation that "good citizen" companies would recognize duties to avoid stakeholder harms and to contribute to societal well-being in ways that went beyond the law and the companies' economic mission. Corporate social responsibility was meant, originally, to be a complement to government-not a substitute (Frederick, 2006; Wood, 1991).

Corporate social responsibility (CSR) was originally framed as a voluntary social control mechanism whereby business organizations would fulfill all their duties in the absence of, or without a need for, over-restrictive government intervention (Frederick, 1994). However, "voluntary" fulfillment of responsibility is in an important sense a contradiction in terms - duties require enforcement mechanisms - and the CSR concept has unfortunately come to be associated in practice with voluntaristic philanthropy and community relations (Wood \& Logsdon, 2002; Logsdon \& Wood, 2002). The concept of corporate social performance then emerged as a way of organizing the inputs, throughputs, outputs, and outcomes of corporate activity so that stakeholders could perhaps achieve the transparency and assurance of goal attainment that is required for their legitimate interests to be met (Carroll, 1979; Wartick \& Cochran, 1985; Wood, 1991). Next, stakeholder theory began to offer specifics about to whom a company should be responsible and about what specific interests and rights were at risk (Freeman, 1984; Mitchell, Agle, \& Wood, 1997). Without authoritative intervention, however, these interests often remain unfulfilled and the rights debased or violated.

In this era of globalization, it is imperative that we all hold corporations accountable for meeting their economic goals in socially responsible and ethical ways. Capitalist business is the most efficient way we know of to organize an economy, but free markets, without any government intervention or countervailing powers, are not the most effective way to achieve societal goals such as environmental sustainability, human rights, and justice. Corporations that cannot earn profits legally, ethically, and responsibly do not deserve to survive, nor can our planet afford for businesses to continue to treat their stakeholders as just another "environmental factor" to be "managed." 
In common practice, CSR often offers companies an opportunity to look good and perhaps to offset negative consequences of their operations through image management. But in its highest and best usage, CSR offers a conceptual mechanism for corporate self-control in conditions of institutional failure to control. Western regulatory history tells us that government and business are natural allies, not enemies; where governments fail to create the legal and normative infrastructure that balances property rights with other stakeholder rights, where businesses find themselves in a chaotic environment, the strongest businesses will seek to rationalize and stabilize that environment by creating and enforcing ground rules-voluntarily at first, and ultimately by supporting government action in support of a "level playing field" (Mitnick, 1981).

Economist Akerlof is correct that "government is often inefficient" (Uchetelle, 2007). But, given what we know about human, organizational, and institutional behavior, government is the most effective vehicle for implementing necessary social controls in support of environmental protection, human rights, and justice (Goodsell, 1983). In the absence of appropriate government controls-where governments are weak, authoritarian, or corrupt- corporate social responsibility is a second-best stand-in for the broad-based interests of stakeholders and society as a whole. Stakeholder theory and corporate social responsibility cannot offer a complete solution for addressing the problems of business in society. They can, however, point to a need for social controls to encourage the beneficial effects of institutional behaviors and to regulate or prevent the harmful effects.

\section{Ending the So-Called "Friedman-Freeman" Debate R. Edward Freeman}

$\mathrm{T}$ The more I read about what has come to be called stakeholder theory, perhaps the more embarrassed I get for having had some minor role in its beginning. The good news is that people are taking these ideas seriously, but there is a critical point at which I part company with many stakeholder theorists. We need to understand stakeholder theory along the following lines.

Milton Friedman, Oliver Williamson, and Michael Jensen are stakeholder theorists. By saying that, I mean that if one understands the spirit of their work, some of the actual words they have recently said, and if we have a slightly more expressive idea of business than have most economists, then the tensions between economists and stakeholder theorists simply dissolve. Since Milton Friedman is not with us anymore and hence can't argue against this view, I'll use this occasion to end the so called "Friedman-Freeman debate." I put that in quotes because frankly there is a little too much hubris in even putting my name in the same sentence as Friedman's. I do so only in the context of those two articles that get reprinted together in many textbooks. One can only stand in awe of Friedman's substantial contribution to our understanding of markets, monetary policy, international trade, and the role of freedom in democratic, market societies. 
As a pragmatist, I tire of the debate between what's normative, what's descriptive, and what's instrumental. It really leads nowhere for lots of good reasons. As a Deweyan, I tire of the debate between what really is the purpose of a firm-in other words, what are the means and what are the ends. Dewey showed us many years ago that means have a way of becoming ends which subsequently have a way of generating new means. That's a more interesting way to think about stakeholder theory. As a capitalist and a diehard libertarian who believes in human freedom and hope, and community solidarity, as two sides of the same coin, I tire of these debates that don't do much to create value.

To begin I want to suggest how to get stakeholder theory off the ground. There is no need for a "normative foundational justification," as many have suggested. We do need some simple and very practical ideas. I'll then suggest why I think Friedman, if you read him correctly, is really a stakeholder theorist. There are four main ideas that get stakeholder theory off the ground: (1) the separation thesis; (2) the integration thesis; (3) the responsibility principle; and (4) the open question argument.

The separation fallacy is fairly straightforward, as Sen and others have suggested. ${ }^{\prime}$ I have written about this ad nauseum elsewhere. ${ }^{2}$ The basic idea is that it's not useful anymore to separate questions of business and questions of ethics. That's what's behind Donaldson's idea of a normative revolution in business (cf. Donaldson, below). I think it is more useful to call it an "integrative revolution." It's about how to put the normative part of business and the other parts together. That's more interesting and useful than just focusing on the normative part. One implication that Donaldson and others draw is that business needs a normative justification. I take that to imply that we need a conceptual apparatus in business that does not commit the separation fallacy. However, a second, and perhaps more important implication is that we would have a more useful ethics if we built into our normative ideals the need to understand how we create value and trade. That's the piece that often times is missing in discussions about corporate responsibility. We take it as if this normative world really has nothing to do with how we create value and trade for each other. But just as people have been watching the stars for a long time, we've also been creating value and trading with each other since long before there were corporations. That is why I want to suggest that we need this integrative revolution, rather than the normative one.

So, the integration thesis is just a way to say that we need to put those things together. It says that it really doesn't make any sense to talk about business without talking about ethics and that it doesn't make much sense to talk about ethics without talking about business. An implicit assumption here needs to be made explicit, and that is: it doesn't make any sense to talk about business or ethics without talking about human beings. We need to make this explicit because there is a dangerous counterrevolution going on in business schools. Much of the theory that we teach in business schools is based on partial theories of human beings which are often derived from the separation fallacy (such as agency theory). They are not theories of whole, fully integrated human beings, with names, faces, families, and pasts, 
i.e., theories about actual businesspeople. The integration thesis implies integrating business and ethics, around the ideas of what a human being is and can be.

The third idea is the responsibility principle, or set of principles. There is nothing foundational or essentially normative here. The idea is a common sense one. If ethics has any meaning whatsoever, if it "gets off the ground" and is meaningful to us as human beings, it will be because we need to justify our lives to ourselves and to others, as Sartre and other thinkers have shown us. Somewhere in this justification we usually find the idea of responsibility for ourselves and our actions. "Responsibility" may turn out to be a very messy idea, even more so in business precisely because we have separated it from the main ideas about business, but whatever view of responsibility people may have, I want to suggest that it's appropriate to build it into the very fabric of business. Now, I actually believe that most people, most of the time, want to take responsibility for the results of their actions on others. It is easy to see how such an idea is simply incompatible with the separation fallacy. If business is on one side and ethics is on the other, then we'll have a gap that may come to be known as "corporate social responsibility." I want to suggest that we avoid this gap by having some integrated way to think about business and ethics, and the idea of responsibility seems to be a good way to start. Of course there may be other places to start, and I hope we see a flourishing of this kind of integrated theorizing, rather than the now tiresome arguing with economists.

The last idea for getting stakeholder theory off the ground is indebted to an argument of G. E. Moore called the "open question argument." Applying this argument here goes like this: For any decision that a manager or other organization member is going to make, are the following questions meaningful (even though they may admit of many different and controversial answers: (1) If this decision is made, for whom is value is created and destroyed, who is harmed and benefited? (2) Whose rights were enabled or not? (3) What kind of person will I be if I make this decision this particular way? Since it is possible to always ask these ethical questions about any decision, it follows that we need to give up the separation fallacy. We need to find ideas and concepts that help to integrate ethics and business.

All this is pretty straightforward and I've been an endless broken record about this for a lot of years. But, it is only recently that I have begun to see what happens when you put these four ideas together, to wit, we get all the justification for stakeholder theory that we need. ${ }^{4}$ The summary is this. The open question argument invalidates the separation fallacy, so take the integration thesis, and add some idea of responsibility, and it seems to me you have to come to something like stakeholder theory. Businesses and executives are responsible for the effects of their action. They are responsible precisely to those groups and individuals that they can affect or be affected by. At a minimum, understanding business means thinking about customers, employees, suppliers, communities, and financiers. Other groups are at least important, as Robert Phillips has argued, in so far as they affect these definitional stakeholders. ${ }^{5}$

Now, let's see what this has to do with this so-called "Friedman-Freeman" debate. 
Should executives seek to maximize shareholder value, or create as much value as possible for stakeholders? Friedman claims that it may be in the long run interest of a major corporate employer in a small community to devote resources to provide amenities to that community or to work to improve its government. In these and many similar cases there is a strong temptation to rationalize these actions as an exercise of social responsibility. Friedman says something like, "well, it's not social responsibility. It's just capitalism." He says that the purpose of a business is to use its resources, engage in activities designed to increase its profits so long as it stays within the rules of the game-that is to say, engages in open and free competition without deception or fraud.

This sounds a lot like the arguments that I have just given for stakeholder theory. You could juxtapose Friedman's view with mine, but that might turn on what you mean by deception or fraud, or open, free competition. It is plausible to claim that "without deception or fraud and subject to ethical custom" just means "ask and answer the questions from the open question argument, and take some idea of responsibility into account, since it is a large part of ethical custom however you parse that idea." So, in principle it doesn't look like there is much disagreement. ${ }^{6}$ It turns out that Friedman himself has really sort of given us a way of integrating the ethical or normative side into business. Friedman thinks that voluntarism is itself a normative view with a long history of justification with respect to principles around freedom.

Another way to see the so-called debate is to try to understand what Friedman means when he says the only responsibility of the executive is to maximize profits. ${ }^{7}$ Perhaps, like many economists and finance theorists, Friedman is most interested in how markets work, and has as his underlying metaphor a discrete transaction that is one among many. However, a more nuanced understanding of business, which Friedman sometimes seems to countenance, would claim that maximizing shareholder value might look like this: "You've got to have great products and services people want, that do what you say they are going to do. You need suppliers who want to make your company better, and who stand behind what they do. You need employees who show up and want to be there, be creative and be productive. You need communities for whom you are at least a good citizen so they don't use the political process (in relatively free societies) to destroy the value you create. And, you have to make money for the financiers." Such a nuanced view of business claims that there is a jointness to these interests, and that the key idea about capitalism is that the entrepreneur or manager creates value by capturing the jointness of the interests. Yes, sometimes the interests are in conflict, but over time they must be shaped in the same direction. If something like this is viable, then the so-called debate is just a disagreement about how business actually works. There is no fundamental value disagreement here, just a disagreement about what it might mean to maximize profits. ${ }^{8}$ I think maximizing profits is more like creating value for stakeholders than others might read in Capitalism and Freedom (Friedman, 1962). Does that mean that I believe that "maximizing profits" is the goal or purpose of the corporation? Absolutely not. I believe that it is an outcome of a well-managed company, and 
that stakeholder theory is an idea about what it means to be well-managed. Profits and purpose are two different ideas, and collapsing them is like concluding from the fact that I need red blood cells to live, that the purpose of my life is to make red blood cells. There are lots of purposes for a business, and any resemblance among all of them is just what Wittgenstein called a "family resemblance."

A second disagreement may well be that Friedman thinks that if you want to maximize profits you should try to maximize profits. And I believe, with Collins and Porras (Collins and Porras, 1994), that as Aristotle and Mill have suggested, profit may be one of those things for which that simply doesn't work. If a business tries to maximize profits, in fact, profits don't get maximized, at least in the real world. The reason may be clear: tradeoffs are made in favor of financiers, and the tradeoffs are false ones due to complexity, uncertainty and bounded rationality. Again, there is not much a debate here, aside from that about which set of ideas is more useful for understanding business.

Indeed the biggest point of departure between Friedman and stakeholder theory as I see it may be over what the two ideas are ultimately "about." Friedman and his followers may be giving us a theory about the way markets work under certain kinds of conditions, and this theory is useful for certain purposes. Stakeholder theory, in my view, is not about markets and how they work (at least first and foremost not about that). It's not a theory of the firm. ${ }^{9}$ Rather it is a very simple idea about how people create value for each other. It's a theory about what good management is. ${ }^{10}$ The so-called debate may be only a difference about the best way to understand how business works and could work, and a difference about what the "theories" are about. And, that's not so much a debate as a "failure to communicate." So Milton Friedman, I would argue, could have written this paragraph:

The primary responsibility of an executive is to create as much value as possible for stakeholders because that's how you create as much value as possible for shareholders. Where there's conflict between stakeholders and shareholders, executives have to rethink the problem so the interests go together. No stakeholder interest stands alone here. Where interests conflict, the job of the manager is to figure out how to redefine things so as to create more value for both. Sometimes this involves making tradeoffs in the real world. When that happens, the executive has to figure out how to make the tradeoffs and figure out how to improve the tradeoffs for both sides. Managing the stakeholders is about creating as much value as possible for stakeholders without resorting to tradeoffs, or fraud and deception.

Better stakeholder theory focuses us on the multiplicity of ways that companies and entrepreneurs are out there creating value, making our lives better, and changing the world. And it needs to focus on cases where things go wrong. So, I'm going to welcome Milton Friedman to the big tent of stakeholder theorists, while at the same time declaring that the wholesale application of the transactional market is not the only useful way of understanding business. Stakeholder theory offers a different set of metaphors and ideas, with hope that we can make capitalism work better for us. 


\section{Non-Rational Behavior, Value Conflicts, Stakeholder TheORY, AND Firm BeHAVIOR \\ Michael Jensen}

$\mathrm{T}_{\mathrm{e}}$ The issues that we are talking about are very important, and I'd like to start by emphasizing some things that I think cause misunderstandings among us. As I listen to my fellow panelists I find myself in agreement with much, but not all, of what has been said, yet my frustration is we don't have a solution for the underlying issues. A minor correction that I would ask of my fellow panelists is to stop using stockholders as the whipping boy. Stockholder value maximization has been wrong from the social viewpoint from the start. There is nothing special about stockholders in the firm. I've said this many times before this, and it is time we take it as given. that maximizing the value of a firm's equity will not produce maximum value of the firm as a whole. And it will certainly not produce maximum value for society.

Maximizing total firm value will get us to the efficient frontier for society assuming there are no single price monopolies, no externalities, and all goods are priced.

The issue as I see it is as follows: If we were able to set the rules of the game for the system we're designing, what sorts of behavior would we want corporations in our system to engage in? My answer is that we want our corporations to behave so as to maximize the total long run value of the firm.

In this system we have to take great care to take account of the appropriate role of government. To allow society to use its human and non-human resources most efficiently the government must do a number of things. Oversimplifying somewhat, it must create a system in which it, the government, has a monopoly on the use of physical coercion and violence in society. It must use that monopoly on the use of violence to prevent citizens from using physical violence on each other, to maintain peace, and to enforce voluntarily entered into contracts among and between its inhabitants. This also means by the way that the government must somehow stop the human beings who run the government at the local, state, and national levels from "renting out" the police powers of the state to private parties who wish to use such powers to steal from others in the system.

The government must also set rules of the game so that the costs imposed on society by externalities are minimized. By externalities we mean the costs (or benefits) imposed by the physical effects of one person's actions on others for which the actor does not bear the costs (or benefits). The classic examples of course are water and air pollution. The problems created by externalities cannot be solved at the private level by individuals or by corporations. These problems can only be solved by collective action through the government and we must start by recognizing this fact. Because externalities have to be solved at the level of the government (the rule maker) calling on the corporation or individuals to solve those problems is a losing game.

If as a rule maker, we could design a system in which the corporate entities in the system behave so as to maximize the long-term value of the firm that would be 
a huge step forward. It will not solve all issues, of course, but it would go a long way to maximizing the size of the pie that determines living standards in society.

The danger with stakeholder theory, as I've seen it expressed in most cases, is that those who advocate it simply assume managers would do the right thing so as to benefit society as a whole. That position is naïve for at least two reasons. Managers would have no way to know how to best benefit society, and furthermore there would be widespread disagreement on how and what to do. Moreover, if adopted, stakeholder theory would do further damage. It would literally leave managers unmonitored and unaccountable in any principled way for their actions with the vast resources under their control. Now that's a disaster.

We observe all around us how public sector managers and representatives fail to provide public services that come anywhere close to maximizing the benefits the public receives from assets turned over to federal, state and local governments. Corporate managers would be little different under stakeholder theory.

The proposition that managers would be unmonitored and unaccountable for their behavior was one of the logical propositions that I made in my 2002 article on stakeholder theory. It involves the proposition that you cannot maximize in more than one dimension at a time. So, the problem associated with determining the overall corporate objective has to be resolved, and my quarrel with stakeholder theory in that article was that there was no resolution of that problem by stakeholder theorists. And I argued there that stakeholder theory would be very popular with managers because it leaves managers and boards unaccountable for how they use the resources of the firm. And that would be a social disaster.

So the question that I think we are addressing is how do we want to set the rules in this game so that human beings are as well off as possible? There are certainly problems associated with income distribution issues and with monopolies, and with non-priced goods, and so on. Let us not lose sight of the fact that there is significant danger here in that attempting to make managers directly responsive to the social welfare, with no way to actually bring that about other than "hope," we kill the goose that lays the golden egg. And by that I mean the system that provides incentives for firms to serve their customers, employees, suppliers of financial and other real resources or to lose out in the competition for survival.

I argue in my 2002 Business Ethics Quarterly article that enlightened value maximization is equivalent to enlightened stakeholder theory. And these systems would meld the concern for stakeholders expressed in stakeholder theory with the notion that the appropriate rule for decision making and action in the corporation would be maximization of the long run total value of all financial claims on the corporation.

And let's be clear in passing that long run value maximization cannot be realized by ignoring or mistreating any corporate stakeholder, be it customers, employee, suppliers, or community.

There is nothing about the system that I envision that requires human beings to be rational. And yet in the typical expression of stakeholder theory it is implicitly assumed that all human beings are rational. 
Indeed we must design a system that deals with the fact that human beings are not rational in something on the order of 50 percent of their lives. I spent seven years with the Mind, Brain Behavior Initiative at Harvard (including membership on its steering committee) in my search for the source of the systematic non-rational behavior of human beings. And by that I mean not only people out there in the world, but every single person in this room, including me. The source of this non-rational behavior lies in the basic structure of the human brain. Neuroscientists have now uncovered the structure that leads all humans to engage in this non-rational behavior. I won't go through the details here, but it is the source of what Richard Thaler and others have characterized as self-control problems or agency problems with ones' self. This is the source of a very large amount of difficulty in the world in which we exist, not only in corporations, but in families, in partnerships, and in governments, indeed in all social institutions as well as all human interaction.

And what we are looking for is a set of rules of the game that can control this not very attractive part of ourselves; that part of all of us which leads us to take actions that hurt ourselves, hurt our loved ones, hurt our firms, hurt the people around us, and then refuse to learn about the damage we are causing. Now that's a serious problem and, as I said above, my guess is that roughly fifty percent of human behavior falls in that category. Looked at from this viewpoint we can see that a large amount of the problems we're struggling to get resolved has this non-rationality of human beings as its source, not simple value maximization of firms. Non-rationality is, of course, not the only source of damage in society. Pure selfishness (the lack of concern for others), and people who are basically evil also contribute to the problems.

The role of the government, which is endogenous in this system, is an incredibly difficult part to get right. Alchian and Demsetz and others, a long time ago, pointed out that it is a fallacy to assume that the government, the rule maker, is not selfinterested and is not subject to these self-control problems, or is not evil (Alchian \& Demsetz, 1972). If we look around the world, we see that the self-interested nature of public agents who have both self-control problems and/or are evil is a huge part of the problem faced by societies. Consider the damage caused by poor behavior on the part of public servants in Africa, Asia, South America as well as what we think of as the "developed" world. As I said earlier the essential role of the government is that we citizens give to the government the monopoly on the right, to use violence and coercion on all of us to keep peace in the "family." Now controlling the exercise of the power that comes with the grant of this monopoly over the use of violence is obviously very important. We've never gotten it perfect. The heinous crimes that are committed against humanity by states around the world is sufficient evidence of the magnitude of this control problem. In the west we've come close at times, but even here it often fails. But if we look to the east, for example Islamic states where there is no separation of church and state, we can see the huge problems that arise. Even here in this country, one of the best democracies in the world, we are certainly not perfect. There is a tendency for our representatives in Washington and state and local governments (to put it crudely) to "rent out" the power of the 
state (the gun) to private individuals and organizations who use the power to steal from the rest of us. One only need look at the vast literature on the capture theory of regulatory agencies to see some obvious examples.

When I look at the maladaptive behavior in corporations (and goodness knows there's lots of it), what shocks me is how much of it is purposeless. What I mean by that is that the behavior doesn't accomplish what the people who are taking those actions nominally want to accomplish, which let us assume is power and wealth. Instead we get the destruction of Enron, the destruction of Arthur Andersen and a parade of CEOs going to jail.

In addition, I believe that even the people who nominally win this game, lose. They lose personally. They lose in terms of the lives they lead, even though they are not in jail and may have great wealth. That's not easy to see, because those stories are not told very often, but out-of-integrity behavior leads to a real mess in people's lives. So in light of all the evidence of the imperfection of human beings we would be foolish to put that power in the hands of managers operating in a system that has no way to hold them accountable for their actions in a principled way. That is my concern with the usual statements of stakeholder theory. This sort of wishful thinking will get us into real difficulty.

Having said all this let me say also that I see that the current system has its own failings. How do we get managers to see that narrow-minded short-term value maximization leads to harm? We see the damaging results of this behavior all around us. So here the problem is how to get managers to avoid falling into the narrow short-run stock price maximization that leads easily to value destruction. I do not have an easy solution to this problem. How do we get managers to see that you cannot exploit your customers, your employees, your suppliers, and your community and create long term value.

I want to add my word to that of my fellow panelists. I don't think we've come anywhere near close to resolving how to incorporate the normative values of human beings into these positive theories of human beings and human institutions that we've been discussing today. I mean by this our discussions of how the world behaves and how we can make it better. I've spent much of the last two years of my life with two coauthors working on a positive theory of integrity. It would take too long to summarize that still unfinished work so I won't even try today. What we intend to create is a way of looking at these normative issues that eliminates the massive amount of confusion that exists regarding the notions of integrity, morality and ethics. Our goal is to create a path by which new power becomes available to individuals and corporate executives, to accomplish things that weren't accomplishable before. If successful, we will convince my economist and management colleagues that integrity, as we define it, is a very important factor of production. By that I mean it is at least as important as technology and knowledge. In my own experiments with my life, those around me and my firm (SSRN), I've seen the results-300 percent increases in productivity, and substantial increases in people's joy. The title of this 
work is: "Integrity: A positive model that incorporates the normative concepts of morality, ethics, and legality."

But right behind this is a problem that I think has been generally unaddressed-the problem of creating a positive theory of normative values. Now I realize that sounds like a non sequitur. However the values that exist in groups, in companies, in societies, in cultures, and in subcultures, arise from somewhere and they are not all the same. These normative beliefs have within them enormous power for both good or bad. We generally see these values as the source of much of what is good about human beings. Yet they are also responsible for much of what is bad about human beings. These normative values lie at the heart of an enormous amount of violence that humans commit against their fellow humans. They lie at the heart of the war that is going on now between radical Islam and the western world. And it is likely to be a hundred years before we see the resolution of this conflict.

So these differences in normative values, the very things that we all showed up to talk about today, are enormously important, both in creating peace and cooperation and unfortunately in creating conflicts and violence, and destroying value and living standards. And we as analysts, theorists and empiricists know almost nothing about how values arise and most importantly, how they create conflict and destruction.

And as I step back and see the debate about stakeholder theory versus stockholder theory I believe we are involved in a small scale example of the problems surrounding conflicts over values. And there is way too much noise, way too much sloppy thinking, and way too little empirical evidence present. But I think we are on the verge of a shift in the profession in these matters. We have seen a shift in the evolution of economics, finance, and management, over the last forty-five years. I believe we are now getting much closer to a concentrated attack on these value issues that may go beyond simple disagreements about what is better or worse or right or wrong.

There is a lot to be done, but the payoffs are enormous, so I want to endorse the efforts of those in this room who are interested in these problems and issues, including my fellow panelists. We have disagreements, but on this fundamental issue, I don't believe there is any disagreement. These are very important issues. And we are still fumbling around in the dark. The issues are very, very complicated. They have deep roots in evolution, biology and philosophical and religious traditions. They are some of the most difficult issues that I've seen in my years in this business. While I see many of my colleagues in finance and economics, (from my personal standpoint) wasting their time, for example, developing ever more precise mathematical models of agency problems or cute game theory exercises, these value issues go unaddressed. These important issues are not getting nearly enough attention from those of us in business and in economics, as well as in the rest of the social sciences. So thank you very much for this discussion today. 


\section{Two STORIES}

\section{Thomas Donaldson}

\section{Twant to tell two stories.}

1 Once upon a time, millennia ago, someone leaned back and looked up at the night sky. He or she noticed that the movements of the bright spots above appeared in a fixed pattern, that all of them traveled in the same direction, and as he watched night after night, he began to recognize a remarkable and perfect regularity. It was awe inspiring. Indeed, he and others slowly came to the conclusion that what they were witnessing was ideal and divine. Even Aristotle, Plato and the majority of other ancient scientists later came to accept the idea that the celestial bodies constituted divine, heavenly bodies, and that they moved with perfect regularity. As time went by, sky watchers developed more accurate measuring devices and were able to make accurate predictions about the movement of the celestial objects. They created elaborate and accurate collections of data about the behavior of what they saw. This was all quite useful. It resulted in more accurate calendars, and in predictions of lunar eclipses. And it helped navigators.

Of course they assumed that the earth was fixed in the heavens. They had no reason to suppose otherwise. But there were nagging discrepancies. Some of the objects tended to show up at odd times and behaved in different ways over a series of nights. Smart people began to work on the problem. They demonstrated that if you assumed that certain kinds of celestial objects traveled in regular orbs, but that others traveled inside those orbs in smaller orbs of their own, you could still predict the movement of the irregular objects. The system was complex, but it worked. Hence there came to be the famous "epicycles" of the Ptolemaic system.

Over a long period of time we abandoned this picture of the heavens. I emphasize that it was a long period of time, because while we think of the Copernican revolution as a sudden flash of inspiration, there was disagreement over many centuries, among intelligent people, about whether to abandon the Ptolemaic system or not. Nonetheless, as we all know from our grade school science class, eventually the solar-centric conception was substituted for the geo-centric one. Even though the epicycles could account for solar-centric behavior, the Copernican conception was much simpler.

This Copernican revolution, however, did not throw out a good bit of what people had learned before. Most systems of measurement remained intact, as did most of the tools used to make such measurements. Of course the tools evolved in their precision and sophistication, but the change was incremental. Calendars remained more or less unchanged. Frankly, for navigators it made little difference whether their scientific friends defended the Ptolemaic or the Copernican conception. A complicated Ptolemaic system with its many epicycles could do the work that a simpler Copernican conception could. Navigators mostly cared about getting their ships safely in and out of port.

That's one story. Here's another story, this time told from the vantage point of our future. 
Once upon a time, millennia ago, someone looked out on the market place and wondered how to make sense of it and how to make it work more effectively on behalf of people in the community. Of course he assumed that there was, more or: less, a fixed amount of wealth to be distributed. He had no reason to assume anything else: the money in his pocket must have come from the pockets of somebody else. This, the first cut at a rational understanding of economic markets, resulted in the period that we now refer to as "mercantilism." Mercantilism inspired a large body of advice on how to trade smartly and well, and how to manage trade relations among nations in order to maximize one's own nation's wealth (Ogg, 1961).

But later, after much government waste and bad regulation (mercantilism fueled embargos, quotas, and other trade restrictions in its attempt to pile up the gold in national treasuries), a young moral philosopher by the name of Adam Smith suggested that we throw out the assumption of the zero sum game (i.e., assuming that there was a fixed amount of wealth) and begin to talk about how wealth is created, especially through labor and voluntary exchange (Smith, 1776).

This theory was very useful. It helped rationalize and make more efficient trade between nations. It helped encourage governments to back away from regulatory activity that was inefficient and that harmed public welfare. Western economies began to expand and an industrial revolution shook the world. Smith's view of more or less self-interested individual human actors engaging in a lightly controlled world of free commerce became dominant in the West.

But nagging problems remained. The most vexing concerned large productive organizations, i.e., what we now call "for-profit corporations." Even Adam Smith was tripped up. In the Wealth of the Nations (Smith, 1776) he devotes only two paragraphs to corporations, and informs his readers that these organizations probably have no real future except perhaps in canal building and banking. We know better now.

As time passed it became obvious that we needed some way of understanding these powerful organizations. It didn't appear that there were markets inside the corporations, so what was happening? And then some very smart people began to suggest that we could, indeed, postulate markets of a sort inside corporations. We need only to remember, they argued, that because there are costs in reaching agreements and making contracts in any kind of market, we can look on corporations as devices for minimizing those "transaction costs." (Coase, 1937; Williamson, 1985) We began to learn things. These theories, too, turned out to be very useful. They helped us understand potential conflicts between the managers of corporations and the owners. We developed elaborate models of markets inside the corporation. I won't call them "epicycles," but they were not entirely unlike Ptolemaic epicycles. Theorists could breathe a sigh of relief. The Smith-inspired vision of the market need not be abandoned after all. Corporations turned out simply to be efficient tools, owned by investors, and used for the same purpose market participants have always had: making money.

The assumption all along, of course, was that Smith's vision of individuals in a 
free market was a vision of a better world, a fairer world, in which most people would be better off. But there were nagging problems for this whole system of thought.

One was: why should a corporation abandon a last minute desperate high risk gamble that was nonetheless the only possible gamble that might save the corporation from bankruptcy, even though the odds were better than even that the result would harm enormously the outside world of customers? Another was that the vision did not seem to explain why managers should respect the rights of employees in instances where doing so is at odds with the pursuit of the maximization of wealth for the owners. Consider Amartya Sen's famous story of Jack and Jill: Jack and Jill are both applying for the same job of supervisor, and the only other job available for either is secretary. Jill has an amazing set of skills. It turns out that she is better qualified to do either the job of secretary or that of supervisor. But it also turns out that if we make Jill the secretary and Jack the supervisor, we will actually get more productivity for the firm. (Jack turns out to be an unreconstructed chauvinist who doesn't work very well with women as bosses.) The theory of the corporation as an efficient agent for its principals (the owners) seems to prescribe that we should hire Jack for supervisor even though Jill is more qualified (Sen, 1987).

Slowly, and in response to many such anomalies, there began to emerge a kind of Copernican revolution, one that came to be called the "Normative Revolution." The corporate function must be justified by something more than the model of unconstrained voluntary transactions in an idealized world of individuals. We begin to understand that we must at some point ask for the normative basis of markets in general, and for the normative basis of the corporation.

It is a revolution that spanned many, many decades. As early pioneers struggled to discover the normative bases of markets and the corporations, some connected the excellence of a market system to the way it often promotes moral rights. Amartya Sen's work, for example, showed a striking compatibility between a market laissez-faire economic system and certain normative principles, especially the right to freedom. (Sen, 1987) Others, including Sen, connected the elegant and powerful advantages of a free market to consequential goods, especially overall aggregate economic welfare. He and others began to move beyond the automatic, but morally disappointing freebee offered by free market theory, i.e., Pareto optimality.

Others offered new theories of corporations and market institutions, honing notions such as "stakeholders" and "social contracts." As with the Copernican revolution, many of the old conceptions and tools were retained. These theorists retained, and continued to refine, the analysis of market transaction and marginal theory. They continued to use rules of thumb, such as agency theory, that helped focus attention on conflicts that hurt investors unnecessarily and unfairly. Some, such as Michael Jensen, argued that unless managers are measured and rewarded solely on the basis of the financial contribution to the shareholders, it becomes difficult to measure their performance accurately (Jensen, 2002). Others showed how terms such as "legitimacy" could reveal dual uses, both normative and predic- 
tive/descriptive, and that these dual-use terms were handy for interpreting corporate behavior (Mitchell, Agle and Wood, 1997).

Now just as for navigators at the dawn of the Copernican era, most business people and investors at the dawn of this new revolution, the Normative revolution, didn't need to choose theoretical sides. They continued to use many of the same tools as before, including models of asset pricing, moral hazard, and supply and demand. They continued to consult empirical researchers who discovered correlations and made predictions. They continued to use models of competitive strategy such as the "five-force" model and the "resource-based" model.

But the end result was a revolution in thinking every bit as profound for economics as the Copernican Revolution was for astronomy.

The parallels between my two stories are obvious. Of course, I told the story about the Copernican Revolution from the standpoint of its historical record, and told the story about the Normative Revolution from the standpoint of extrapolating its current record.

Today, as we examine the Normative Revolution from the position of being in its midst, we can spot two key insights. One is that any economic system or institution whatsoever stands in need of normative justification. This holds especially true for the most important modern economic institution, the corporation. We must eventually abandon justifying such institutions entirely in terms of back-to-front, patched-up theories, such as voluntary transactions and free market systems. We must face up to the questions, as we are beginning to, of "Why does the corporation exist?" and "What are these institutions for?" Corporations, larger and richer than most of us, are, if nothing else, artifacts. We made them; we created them; and we will make them differently in the future. In early work I explained why I think the best way of answering these questions is to think in terms of a hypothetical social contract in which economically interested people in a state of nature, lacking all productive organizations, ask themselves "Should we introduce productive organizations?" And the principal answer such inhabitants of a state of nature will give is that, "Yes, we should introduce productive organizations because they are so darned efficient" (Donaldson, 1982). Hence, it turns out that the principal, although not the sole, moral responsibility of managers is to produce efficiently and satisfy investors and maximize, at least within constraints, their financial welfare. But it should not be surprising that progressive concepts like this and those of other contemporary scholars bear some resemblance to traditional notions of the corporation. The Normative Revolution, just as the Copernican Revolution before it, does not alter the picture of the world entirely. Both Ptolemy and Copernicus could predict that the constellation called Leo will show up in the summer.

Today the stars continue to move, and our normative revolution advances. The second key insight guiding the Normative Revolution is that managers must ascribe some intrinsic worth to stakeholders. That is to say, a stakeholder, such as an employee, must be granted intrinsic worth that is not derivative from the worth they create for others. Human beings have value in themselves. Their rights stand 
on their own. These rights themselves are morally and logically prior to the way in which respecting their rights may generate more productivity for others or the corporation. This is an inescapable truth for the current normative revolution.

In short, the primary goal of the corporation will remain the maximal benefit, i.e., financial benefit, that flows to its owners. The sun still rises. Yet, thanks to the Normative Revolution, we are coming slowly to understand more clearly why that is true. And, most important, in this new, braver economic theory, people matter more.

\section{The JoInt-Stake Company and Accountability For OPPORTUNITY: WHAT IF?}

\section{Ronald K. Mitchell}

Cymposia such as this one-especially where social issues in management are involved-are the place where one can ask "what-if" kinds of questions of import. So in the spirit of "what if," I wonder whether 500 years from now our use of social tools, for example, the corporation, will be lauded or deplored; whether the tools that got us "here" are adequate to get us "there." I also wonder: Is the joint-stock company outmoded? I would like to consider together something that we could call the "joint-stake company," a play on John Stuart Mill's (1848) notion of the joint-stock company.

The joint-stock company idea concerns pooling of resources; specifically that investors pool their resources, each jointly taking stock or ownership in a company so as to accumulate sufficient capital for large ventures. When such a company sent a "ship to the Indies," it was, for example, filled with spices; and if it came back, that cargo was sold for a profit. Over the years, we've embellished this concept; and the development of the modern corporation is the result. Jensen (2002) accurately points out that a key problem for stakeholder theory, unlike joint-stock-company theory where for a variety of reasons it has been deemed to be less-relevant, is the question of keeping managers accountable for their actions with respect to the social goals and values espoused by stakeholder theorists:

Because stakeholder theory provides no definition of better, it leaves managers and directors unaccountable for their stewardship of the firm's resources. With no criteria for performance, managers cannot be evaluated in any principled way. (Jensen 2002: 242)

The questions that I would therefore like to ask are the following: Is there a joint-stake company possibility that can be conceptualized, and, if so, could such an idea be applied to the foregoing dilemmas posed by Jensen (2002)? And if we are willing to go that step, then the step farther would be to ask what would jointstake-firm thinking entail? So this leads us to wonder about all kinds of things that might be impacted by a revised concept of a value-creating enterprise as a jointstake company. The social arrangements impacted might include property rights, taxation systems, currencies, regulation, claims, accountability, and accounting systems. So let's engage in some "here versus there" comparison, and consider how 
Table 2. A What-If Comparison

\section{Social Arrangements}

Market for property rights

Taxation

Currency

Regulation basis

Type of residual claim

Accountability

Basis for accounting
HERE (Joint-stock):

- Stock markets

- Bottom-line-based income tax

- National

- National standards

- Investor*-based claims

- Accountability-to-control

- Historical cost
THERE (Joint-stake):

- Markets for value-network shares

- VAT (value-added taxation)

- Transnational

- International standards

- Opportunity/value-creating

- Accountability-to-opportunity

- "Balance-free accounting" transaction-count proportions

* Explicit v. implicit

accountability fares in the present joint-stock company versus some future jointstake arrangement (Table 2).

"Here" we have stock markets-markets for the equities (property rights to residual earnings) from the pooled resources. We have bottom-line based taxation-primarily income tax. We have national currencies (although there is a notable exception that is beginning to emerge in the Euro), and we have national regulation. We have investmentbased claims (and by this I mean explicit investment as a certain dollar amount to purchase shares of stock), and we have accountability to those with ownership control: accountability to the stockholders. And yes, we have historical cost as the basis for accountability.

Now consider "there": the joint-stake situation. (I do not suggest that the following ideas are what "ought" to be, but I do suggest that this is not quite "whimsy" either, and that sketching the outlines of a joint-stake company might serve the instrumental development of stakeholder theory.) "There" we might find a market for value network-based shares or "stakes" in place of (or in addition to) a market for stocks-claims on participation in the value-creation process. "There" might involve taxation truly based on value added (not the traditional value-added-tax that is legislative sleight-of-hand to simply add more tax over-and-above the income tax.) "There" might involve more transnational currencies. "There" might involve international standards, for example for product safety. "There" we might also find that-instead of our only having investor-based claims-stakeholder claims could be expanded to include contribution-to-opportunity-, and value-creation-based claims (e.g., Schneider, 2002). Consequently, "there" we might find also accountability-toopportunity (i.e., accounting for the favorable occurrences of "what might be," or "what is but might not have been," where opportunity is defined to be a favorable juncture of circumstances).

Pause for a moment and think about the meaning of an idea such as accountabilityto-opportunity. Instrumentally, the practical enactment of accountability-toopportunity encounters the age-old "understatement" problem, wherein auditors find it much more difficult to verify credits (incomes, liabilities and equities) than they do debits (assets and expenses). This is because the evidence required to identify understatement in the GL (general-ledger)-based credit balances (i.e., income, liability, equity) is not readily available. For example, embezzled income would be understated because it would never have been recorded. In this case the 
understatement problem occurs because "what might be" would not ever have been captured in the accounting system. Compare the foregoing "complex" problem with the much "simpler" problem of ascertaining overstatement in the GL debit balances (i.e., expense, asset) which requires only effective and efficient counting processes. If, for example, petty cash (as an asset) has been stolen, this fraud could easily be detected by counting the cash on hand and comparing it to the amount of cash the accounting records say ought to be there. Thus, testing "what might be," or "what is but might not have been," (understatement) is much harder than the simple testing of what "is" (overstatement). Historical-cost-based auditing of opportunities that "may or may not come to be" is therefore problematic due to the understatement problem in balances-based accounting; and thus historical-cost accounting does not serve well the task of accounting for understatement-prone phenomena such as accountability-to-opportunity. In short, historical-cost-balance accounting creates special problems that preempt effective accounting for the unique understatementbased problems encountered in managing and directing the joint-stake company. This has led me to wonder: What about a system of balance-free accounting that might overcome many understatement-driven accounting challenges?

From what perspective do I suggest an expansion of our accounting system to enable accountability-to-opportunity? I come to management scholarship from the accounting field. I am a CPA ${ }^{11}$ who, as part of my training, was required to understand concepts such as the "identity equation," and the many concepts that go into the pronouncements of FASB (the Financial Accounting Standards Board) and its predecessor the APB (Accounting Principles Board) that form the standard-settingbased foundations of the accounting profession. So drawing on this background let's just explore, for example, this one key element of the previous list of "what-ifs": accountability-to-opportunity, as one possible means to enable and implement a principled way for managers and directors to be accountable for their stewardship to stakeholders. This exploration will focus on the accounting relationship under stakeholder theory, simply because (as noted in my quotation of Jensen, 2002) this topic seems to be where the "rubber hits the road." Put simply, if there is no way to make accountability happen under stakeholder theory, how would it be possible to claim superior stakeholder theory?

Herein, however, we can only outline only the bare-bones of a possible expanded system of accounting to illustrate what is needed for a superior stakeholder theory. If 500 years from now we were to look back and say, "we did the Copernican thing," we did preserve what it was that got us "here," but we changed enough to get us "there," perhaps it would include the addition of something called balance-free accounting. Balance-free accounting might be defined in terms that substitute in the place of the historically-developed dollar-cost balances resident in general ledger accounts, information (based on some readily discernable commonality) that accomplishes the comparison objectives of financial reporting (i.e., comparisons of present results to past results, to present (e.g., cross-industry) benchmarks, and to future forecasts/ budgets). Such common bases for comparison have been termed compositional 
similarities (e.g., Chan, 1998; Rousseau, 1985), where commonality-based comparison can be accomplished using, for example functional/additive, direct consensus, referent-shift, dispersion, and process models of compositional similarity (Chan, 1998). Using such models, the development of balance-free accounting might be focused on the identification and explication of systems of compositionally consistent comparison across the past, present, and future. This addition to the accountability lexicon could have helpful consequences, according to the following logic.

Enterprises tend to be enabled and constrained by their measurement systems. There is common wisdom among managers that once one begins to measure something, many other things (e.g., externalities) don't get captured. Enterprise accountability is in this sense constrained by the measurement systems employed. This is one of the reasons that accounting theorists and practitioners have problems with historical cost-based accounting: important phenomena are excluded from the accounting process. For example accounting theorists have, in the past, looked at the underlying reasons for particular classification systems of historical-cost accounts on balance sheets, asking questions such as: On what basis would such classification arise? and Why should historical costs versus, for example price-level adjusted amounts be the basis for accounting statements? (Abdel-Magid, 1979; Mitchell, 1976; Vickrey, 1979). ${ }^{2}$ The accounting literature has addressed many such questions. And over the years (especially in the past two decades or so) the emergence of critical accounting theory has produced studies that "push the limits" of received accounting theory involving similar but not identical questions to those raised herein. Somewhat related topics addressed, for example (but non-exhaustively), include: the political economy of accounting (e.g., Briloff, 1990; Cooper, Taylor, Smith, \& Catchpowle, 2005), critical accounting (e.g., Arthur, 1993; Gallhofer \& Haslam, 1997; Pesqueux, 2005), financial accounting's role in the processes of international capital formation (e.g., Neu \& Ocampo, 2007); management accounting's role in organizing the labor process (e.g., Marsden, 1998), the relationship between accounting and the state in various social formations (e.g., Jönsson, 1994), antagonisms between the social and private character of accounting (e.g., Bryer, 1999; Gray, 1998), and the interplay between accounting, social conflict, and bureaucracy (e.g., Kaghan \& Bowker, 2004). But the construction of dramatically new accounting institutions (e.g., balance-free accounting) to support a substantially new type of company (e.g., a value-network-type joint-stake company), has not yet received much attention in the critical accounting literature. So we appear to be at liberty to wonder together: "what if" (to make such new conceptualizations possible) we were to create a new basis for accountability; and what if that base were to be (for example): transaction counts as they occur in a joint-stake setting? Interestingly, this kind of base-for-measurement technique is already somewhat in place.

An audit, in my experience, begins with a process called APT (the "audit program for transactions"). This process requires the auditor to select-from the financial statements prepared by management-transactions for examination that fit a statistically determined materiality threshold, to invoke the audit of a sufficient number 
and value of transactions, and enable assertions about fair statement of the audited historical accounts. Transactions are the basis for APT, because they have sufficient generality in their attributes such that they are amenable to an audit system that has comparability of financial results as a key objective.

The kinds of metrics that we would therefore find in transaction-based balancefree accounting also would be universal units in this sense. So in the Copernican process discussed by Donaldson (herein), we wouldn't necessarily do away with GL accounts on a balance sheet: the real accounts (the essentials of assets, liabilities and equities) or the nominal accounts (the incomes and the expenses). However, by employing the general properties of arm's-length transactions- exchanges between willing buyers and willing sellers-we could use simple statistics like transaction counts to construct new metrics that expand the accountability system: proportions, for example, for both system classification, and for results reporting.

For joint-stake-company accounting, it would mean that this value-network-type "company" could then become accountable, for example, according to "stakes" computed as a proportion of transaction flow. Perhaps such "value-network-type companies" would account for transaction-based statistics across borders, across jurisdictions, across industries: enabling an "across-across-across" (i.e., a multifaceted compositional) approach that liberates our thinking and our management processes from limiting diminishing-returns-type boundaries. It would be an integrated system in the sense that such ideas have been suggested by the other authors in this article. The flow assumption could be based upon a value chain "system." Of course, we would then require a new identity equation.

The present identity equation used in today's accounting statements is wellknown: assets equal liabilities plus owners' equity. But what if there were to be a system-based identity equation that utilizes transaction counts to establish the proportionate stakes in outputs? In this example the identity equation for balancefree joint-stake company accountability might be based on the well-known system equation: inputs plus process equals outputs (i.e., transaction-count contribution to inputs + transaction-count contribution to processes = proportionate stake in outputs, where the proportion of transactions devoted to inputs, and to production/service processes using such inputs would thereby provide proportions for the allocation of the outputs). To establish accountability on a GL-balance-free basis (to better manage the understatement problem of accountability-to-opportunity) we would in this way provide a means whereby to identify which stakeholders contribute to the input, to the process, and to the output transactions across heretofore traditional boundaries, and within new joint-stake entities. We would thereby capture a great many more un-captured externalities. (Please see Appendix for an example that illustrates and more-fully develops this argument.) The implications of such an approach for further analysis and discussion would be, for example, more-universal comparability, decreases in entropy, and an increase in the value created by the joint-stake enterprise.

Consequently, Pacioli's (1494) "shall give" and "shall receive" notion that 
founds double-entry accounting systems would take on added, amplified, and value-creating meaning. As Venkataraman (2002) asserts: two processes, value creation and value sharing, are common ground for both the study of business and of business ethics. This assertion echoes the writings of Victor Hugo, who in the nineteenth century also suggested that the two main problems faced by any society are: (1) the production of wealth, and (2) its distribution (Hugo, 1982: 722). A new system-based accounting equation might therefore (as it contributes to the establishment of accountability-to-opportunity) also contribute to the production (inputs + processes)/distribution (output value distribution) conversation, thus focusing further attention on the still-present and thorny dilemma (Jensen, 2002) as it concerns both the production and distribution of value: providing a definition for stakeholder-generated "better"; and defining an accountability stewardship that can be evaluated in a principled way.

How would such a system provide accountability-to-opportunity? Could it not be argued that in the same sense that residual claims of stockholders are now divided according to ownership proportion in a joint-stock company, that joint-stake-based apportionment might be possible? Could it not be argued that according to the laws of "increasing returns" (e.g., Arthur, 1996; Appendix) stockholders with property rights in a joint-stake-value-network-type "company" could (for the same reasons they invested) cede to stakeholders (whose incremental-value-creating incentive alignment could effect increasing returns), an opportunity-share of increased residuals (to be apportioned on the basis of balance-free/new-identity-equation-based proportions)? Such somewhat-novel speculation is admittedly "bare-bones," but is offered in the spirit of "what-if" to reopen a dialogue which may have prematurely closed; and instead, to assert that the joint-stake idea need not perish due to accountability problems. I invite you to join in this important conversation, so that 500 years from now it might be said of us: the early millennials were in fact capable of adjusting their social tools to continue to pool their resources both efficiently and effectively.

\section{Conclusion: From Dreaming to Actualization in Stakeholder Theory Development}

\section{Bradley R. Agle and Ronald K. Mitchell}

Clarkson's (1998) dream of superior stakeholder theory sought to redefine the
corporation "as the converter into goods and services of the resources and
stakes that are at risk, to create wealth or value for all its stakeholders, without
exposing them or others to involuntary harm or loss ... and develop an economics
of responsibility embodied in our business ethics" (1998: 9). In her observations,
Wood elaborates this revisionist stance; suggesting that a corporation built upon
our business ethics (v. the reverse) can be the repository of economic responsibility.
And according to Donaldson, this (r)evolution is occurring. We need to help push it 
forward, especially - as argued by Freeman - while developing pragmatic solutions for the millions of managers who go to work each day and run our organizations. Are we building a superior load-bearing stakeholder structure that can withstand the stresses and tests that those who rely on the assertions we make in our research and teaching will, in good faith, place upon it?

As noted by Mitchell, such a structure will require new social tools to be built; current practices refined and changed; and when necessary old tools or ways of thinking to be left behind or rejuvenated, given, as Jensen notes, no lessening of the world's significant problems, with their deep cognitive and institutional origins. While past economic theory has created great economic wealth, Jensen suggests that a newer, better theory perhaps can continue creating this same or better economic value, while simultaneously helping society to create new value in multiple forms, and thereby solve many societal problems. But questions remain.

Why does the stakeholder idea continue to gain in popularity among both managers and academics? And given this growing popularity, to what extent does abstract lip service to stakeholders' concerns translate into concrete, deep-conviction stakeholder-based management? Is the stakeholder idea a passing fad; or is there growing substance in the theoretical underpinnings? Is the seemingly simple concept of stakeholder-focus becoming any simpler to implement than when it was first introduced? Or is the idea not really so simple after all? Questions such as these suggest that to be superior, stakeholder theory should be meeting criteria of a good and useful theory, criteria such as growth in elegance, ease of use, explanatorily efficient, simple (compared to alternatives), and even instinctively pleasing.

As Donaldson has noted, each new step in great theory development builds upon its predecessors. It its progression from Aristotle and Ptolemy, through Copernicus, Newton, and Einstein, and on to the developers of quantum and superstring theory, the hypotheses about our physical surroundings that we have called our great theories of the universe, have become ever more useful. As readers will have noted, within the five themes recounted herein appears evidence that the process of buildingtoward-elegance in stakeholder theory remains incomplete. While stakeholder theory is instinctively pleasing to many (which may account for its growing popularity), its ease of use in concrete, deep-conviction stakeholder-based management, the explanatory efficiency and power of its theoretical underpinnings, and its simplicity in implementation, continue to be works in progress. Needed, therefore, is the inspiration and motivation to continue to build.

Agle, Mitchell, and Sonnenfeld (1999) point to the normative foundations of stakeholder theory as a point of departure to inspire the creation of these better theories, methods, and tools. Jensen (2002) argues that while stockholder value maximization is the goal of the organization; such a goal will not provide inspiration for managers or their stakeholders. Fulfilling dreams requires having dreams worth fulfilling. Superior stakeholder theory is one such dream. Wouldn't it be grand if it could also serve as a means for fulfillment? 


\title{
APPENDIX
}

\section{An Example and Explanation: Increasing Returns, the Joint-Stake Company, and "Balance-Free Accounting"}

\section{Ronald K. Mitchell}

\begin{abstract}
A ccording to Arthur (1996: 100) increasing returns exist alongside those of diminishing returns in all industries, and are defined to be: "the tendency for that which is ahead to get further ahead and for that which is losing advantage to lose further advantage." In this conceptualization, modern economies contain two interrelated worlds of business corresponding to the two types of returns, each with different economics, behavior, style, culture, management techniques, strategies and codes of government regulation, etc. These differences are often illustrated by explanations of how increasing returns operate in high tech and in service industries. But because these differences can apply wherever socioeconomic momentum occurs, the notion of increasing returns can reasonably be applied to the joint-stake "company" as the following example helps to illustrate.
\end{abstract}

Consider "the market for operating systems for personal computers in the early 1980s when CP/M, DOS, and Apple's Macintosh systems were competing. Operating systems show increasing returns: if one system gets ahead, it attracts further software developers and hardware manufacturers to adopt it, which helps it get further ahead. CP/M was first in the market and by 1979 was well established. The Mac arrived later, but it was wonderfully easy to use. DOS was born when Microsoft locked up a deal in 1980 to supply an operating system for the IBM PC. For a year or two, it was by no means clear which system would prevail. The new IBM PC DOS's platform was a kludge. But the growing base of DOS/IBM users encouraged software developers such as Lotus to write for DOS. DOS's prevalence-and the IBM PC's_-bred further prevalence, and eventually the DOS/IBM combination came to dominate a considerable portion of the market. That history is now well known. But notice several things: It was not predictable in advance (before the IBM deal) which system would come to dominate. Once DOS/IBM got ahead, it locked in the market because it did not pay for users to switch. The dominant system was not the best: DOS was derided by computer professionals. And once DOS locked in the market, its sponsor, Microsoft, was able to spread its costs over a large base of users. The company enjoyed killer margins.

These properties, then, have become the hallmarks of increasing returns: market instability (the market tilts to favor a product that gets ahead), multiple potential outcomes (under different events in history, different operating systems could have won), unpredictability, the ability to lock in a market, the possible predominance of an inferior product, and fat profits for the winner." (Arthur, 1996: 102)

As an alternative to the traditional model, accountability-to-opportunity-type 
accounting assumes externalities to capital (e.g., Duncan \& Pollard, 2001: 4), which can spill over to the whole economy and produce increasing returns to scale through, for example, "learning by doing" mechanisms (Romer 1986, Lucas 1988) or research and development (Grossman and Helpman 1991; Romer 1990), under conditions of market instability, multiple potential outcomes (depending upon how history is shaped), and customer learning effects. Accordingly, system-based accountability-to-opportunity achieved through, for example, the incentive alignments made possible by balance-free accounting within the joint stake enterprise, ${ }^{13}$ could invoke increased learning by doing, network driven, customer learning, and history-writing based momentum that could yield the increases in value created (such as externalities to capital) which become available to enable expanded output-stakedriven distribution. The question therefore is not how, after the fact, Microsoft's profits should be split differently; rather it is-given the positive externalities to capital possible with an in-fact better operating system (e.g., CP/M or Mac)—could accountability-to-opportunity have changed history for the better; and with it, the magnitude of increasing returns from a $\mathrm{CP} / \mathrm{M}$ or Mac triumph? The premise is that the value-network/joint-stake-company can do more to add value if the accountability proportions to input- and process-stakeholder contributors are solved. Hence, accountability-to-opportunity is fundamentally an understatement problem ready to be tackled with new tools invoked by the joint-stake idea. Joint stake-company ideas and ideals offer a viable "what-if." In other words: accountability-to-opportunity for all concerned, using new concepts such as balance-free accounting, can reasonably be considered - as a thought experiment-to point toward practicality in joint-stake-company accountability.

\section{Notes}

Notes 1-10 are from Freeman, pp. 162-166; notes 11-13 are from Mitchell, pp. 176-181, and the Appendix, pp. 183-184.

1. Amartya Sen, On Ethics and Economics (Oxford: Wiley-Blackwell, 1991).

2. For the latest argument, see R. Edward Freeman, Jeffrey Harrison, and Andrew Wicks, Managing for Stakeholders: Survival, Reputation and Success (New Haven, Conn.: Yale University Press, 2007).

3. See G. E. Moore, Principia Ethica (Cambridge: Cambridge University Press, 1903).

4. In fact this is due to working with a number of co-authors, Jeffrey Harrison, Andrew Wicks, Simone deColle, and Bidhan Parmar, on a book tentatively titled Stakeholder Theory and Business, which we hope to complete in 2008.

5. Here I am suggesting that it won't be very useful to talk about "business" without talking about customers, suppliers, employees, communities, and financiers. I mean to make no ontological claims here, simply a pragmatic suggestion.

6. Indeed one interesting way to teach the so-called debate is to get students to simply dissolve the debate and understand what may be more subtle points of disagreement.

7. This debate is much more important than a textual debate about Friedman and stakeholder theory, since the modern form of the theory of the firm, taught in every finance class in 
every business school, adopts some form of Friedman's argument, without the subtlety and without the understanding that it rests on a number of essentially moral claims.

8. I am indebted to Gordon Sollars for never failing to point out to me that many socalled "moral disagreements" are often just instrumental disagreements about the way the world works.

9. Stakeholder theory isn't about social responsibility. I've been an endless critic of the idea of social responsibility for over twenty years. I like the motive behind CSR, but I think once you spell out corporate stakeholder responsibility, you don't need anything more than that.

10. Whether or not "stakeholder theory" is a "framework" or a "theory" or a "hypothesis" is another one of those uninteresting questions to a pragmatist like me. I hope that it encapsulates some very useful ideas for us to figure out how to create value for each other in a better way.

11. For several years, Mitchell practiced with the firm of Haskins \& Sells, and later Deloitte Haskins \& Sells (one of the former Big 8 accounting firms), now Deloitte \& Touche.

12. Abdel-Magid supervised Mitchell, who assisted on such a project with a background paper in 1976.

13. Balance-free accounting within the joint-stake enterprise is defined in this case to be: proportionate allocation of value created based on a broader conception of the value-creation process in value-network-type "companies."

\section{References}

Abdel-Magid, M. 1979. General-price-level-adjusted historical-cost statements and The Ratio-Scale view: A comment. The Accounting Review, 54 (4): 825-29.

Agle, B., \& Agle, L. 2007. The stated objectives of the Fortune 500: Examining the philosophical approaches that drive America's largest firms. Working Paper. University of Pittsburgh.

Agle, B. R., Mitchell, R. K., \& Sonnenfeld, J. A. 1999. Who matters to CEOs? An investigation of stakeholder attributes and salience, corporate performance, and CEO values. Academy of Management Journal, 42 (5) 507-25.

Alchian, A. A., \& Demsetz, H. 1972. Production, information costs, and economic organization. American Economic Review, 62: 777-95.

Arrow, K.J. 1984. Individual choice under certainty and uncertainty. Cambridge, MA: Belknap Press.

Arthur, A. 1993. Critical accounting theory and practical philosophy: Applying the tools. Critical Perspectives on Accounting, 4 (3): 209-24.

Arthur, B. 1996. Increasing returns and the new world of business. Harvard Business Review (July/August): 100-09.

Bartkus, B., Glassman, M., \& McAfee, B. 2006. Mission statement quality and financial performance. European Management Journal, 24 (1):86-94.

Berman, S., Wicks, A., Kotha, S., \& Jones, T. 1999. Does stakeholder orientation matter? The relationship between stakeholder management models and firm financial performance. Academy of Management Journal 42 (5): 488-506.

Briloff, A. J. 1990. Accountancy and society: A covenant desecrated. Critical Perspectives on Accounting, 1 (1): 5-30. 
Bryer R. A. 1999. A Marxist critique of the FASB's conceptual framework. Critical Perspectives on Accounting, 10 (5): 551-89.

Carroll, A. B. 1979. A three-dimensional conceptual model of corporate social performance. Academy of Management Review, 4: 497-505.

Chan, D. 1998. Functional relations among constructs in the same content domain at different levels of analysis: A typology of composition models. Journal of Applied Psychology, 83 (2): 234-46.

Clarkson, M. B. E. 1998. Introduction. In M. B. E. Clarkson (Ed.), The Corporation and its stakeholders-Classic and contemporary readings: 1-9. Toronto: University of Toronto Press.

Cludts, S. 1999. The stakeholders as investors: A response to Etzioni. Business Ethics Quarterly, 9 (4):673-76.

Coase, R. H. 1937. The nature of the firm. In G. J. Stigler \& K. E. Boulding (Eds.), Readings in Price Theory: 386-405. Homewood, IL: Irwin.

Collins, J., \& Porras, J. 1994. Built to last: Successful habits of visionary companies. New York: HarperCollins.

Cooper, C., Taylor, P., Smith, N., \& Catchpowle, L. 2005. A discussion of the political potential of social accounting. Critical Perspectives on Accounting, 16 (7): 951-74.

Donaldson, T.. 1982. Corporations and morality. Englewood Cliffs, NJ: Prentice Hall.

1999. Response: Making stakeholder theory whole. Academy of Management Review, 24 (2): 237-41.

Donaldson, T., \& Dunfee, T. W. 1999. Ties that bind. Boston: HBS Press.

Duncan, R., \& Pollard, S. 2001. A conceptual framework for a country poverty reduction strategy. Paper presented at The Asia and Pacific Forum on Poverty: Reforming policies and institutions for poverty reduction, Manila.

Egidi, M., \& Marris, R. 1995. Economics, bounded rationality and the cognitive revolution. Brookfield, VT: Edward Elgar.

Ehrenreich, B. 2001. Nickel and dimed: On (not) getting by in America. New York: Metropolitan Books.

Frederick, W. C. 1994. From CSR1 to CSR2. Business \& Society 33 (2): 150-64.

2006. Corporation be good!: The story of corporate social responsibility. Indianapolis: Dog Ear Publishing.

Freeman, R. E. 1984. Strategic management: A stakeholder approach. Boston: Pitman.

Freeman, R. E., Wicks, A., \& Parmar, B. 2004. Stakeholder theory and "the corporate objective revisited" Organization Science 15 (3): 364-69.

Friedman, M. 1962. Capitalism and freedom. Chicago: University of Chicago Press.

Frooman, J. 1999. Stakeholder influence strategies. Academy of Management Review, 24 (2):191-205.

Gallhofer, S., \& Haslam, J. 1997. Beyond accounting: The possibilities of accounting and "critical" accounting research. Critical Perspectives on Accounting, 8 (1-2): 71-95.

Goodsell, C. T. 1983. The case for bureaucracy: A public administration polemic. Chatham, NJ: Chatham House Publishers. 
Gray, R. 1998. Imagination, a bowl of petunias and social accounting. Critical Perspectives on Accounting, 9 (2): 205-16.

Grossman, G. M., \& Helpman, E. 1991. Innovation and growth in the global economy. Cambridge, MA: MIT Press.

Hall, J., \& Vrendenberg, H. 2005. Managing stakeholder ambiguity: Companies increasingly need to engage a wide range of stakeholders, but managers often underestimate the complexity of the task. Sloan Management Review, 47 (1):11-19.

Heath, J. 2006. Business ethics without stakeholders. Business Ethics Quarterly, 16 (4): 533-57.

Hendry, J. 2001. Missing the target: Normative stakeholder theory and the corporate governance debate. Business Ethics Quarterly, 11 (1):159-76.

Hillman, A. J., \& Keim, G. D. 2001. Shareholder value, stakeholder management, and social issues: What's the bottom line? Strategic Management Journal, 22: 125-39.

Hofstadter, R. 1944. Social Darwinism in American thought, 1860-1915. Philadelphia: University of Pennsylvania Press.

Hugo, V. 1982 (1862). Les miserables. Middlesex, Eng.: Penguin Books, Ltd.

Jawahar, L. M., \& McLaughlin, G. L. 2001. Toward a descriptive stakeholder theory: An organizational life cycle approach. Academy of Management Review, 26 (3): 397-414.

Jensen, Michael C. 2002. Value maximization, stakeholder theory, and the corporate objective function. Business Ethics Quarterly, 12 (2): 235-47.

Jones, T., \& Wicks, A. 1999. Convergent stakeholder theory. Academy of Management Review 24 (2): 206-21.

Jönsson, S. 1994. Changing accounting regulatory structures in the context of a strong state. Critical Perspectives on Accounting, 5 (4): 341-60.

Kaghan, W. N., \& Bowker, G. C. 2004. Accounting practices and networks of accountancy: A comment on "what is measured counts" by Kala Saravanamuthu. Critical Perspectives on Accounting, 15 (3): 325-29.

Kochan, T. A., \& Rubenstein, S. A. 2000. Toward a stakeholder theory of the firm: The Saturn partnership. Organization Science, 11 (4): 367-86.

Lakoff, G. 1996. Moral politics: What conservatives know that liberals don't. Chicago: University of Chicago Press.

Logsdon, J. M., \& Wood, D. J. 2002. Business citizenship: From domestic to global level of analysis. Business Ethics Quarterly 12 (2): 155-88.

Lucas, R. E. 1988. On the mechanics of economic development. Journal of Monetary Economics, 22 (1): 3-42.

Luoma, P., \& Goodstein, J. 1999. Stakeholders and corporate boards: Institutional influences on board composition and structure. Academy of Management Journal, 42 (5): 553-63.

Marcoux, A. 2003. A fiduciary argument against stakeholder theory. Business Ethics Quarterly 13 (1): 1-24.

Marens, R., \& Wicks, A. 1999. Getting real: Stakeholder theory, managerial practice, and the general irrelevance of fiduciary duties owed to shareholders. Business Ethics Quarterly, 9 (2): 273-93. 
Marsden, R. 1998. A political technology of the body: How labour is organized into a productive force. Critical Perspectives on Accounting, 9 (1): 99-136.

Mill, J. S. 1848. Of production on a large, and production on a small scale. In J. S. Robson (Ed.), Principles of Political Economy. Toronto: University of Toronto Press.

Mitchell, R. K. 1976. Classification theory. Unpublished working paper. University of Calgary.

Mitchell, R. K., Agle, B. R., \& Wood, D. J. 1997. Toward a theory of stakeholder identification and salience: Defining the principle of who and what really counts. Academy of Management Review, 22 (4): 853-86.

Mitnick, B. M. 1980. The political economy of regulation: Creating, designing, and removing regulatory forms. New York: Columbia University Press.

1981. The strategic uses of regulation--and deregulation. Business Horizons, 24 (2): 71-83.

Moneva, J., Rivera-Lirio, J. M., \& Munoz-Torres, M. J. 2007. The corporate stakeholder commitment and social and financial performance. Industrial Management and Data Systems, 107 (1): 84-102.

Neu, D., \& Ocampo, E. 2007. Doing missionary work: The World Bank and the diffusion of financial practices. Critical Perspectives on Accounting, 18 (3): 363-89.

Ogden, S., \& Watson, R. 1999. Corporate performance and stakeholder management: Balancing shareholder and customer interests in the U.K. privatized water industry. Academy of Management Journal, 42 (5): 526-38.

Ogg, D. 1961. Europe in the seventeenth century, 8th ed. London: A. \& C. Black.

Omran, M., Atrill, P., \& Pointon, J. 2002. Shareholders versus stakeholders: Corporate mission statements and investor returns. Business Ethics: A European Review, 11 (4): 318-26.

Pacioli, L. 1494. Summa de arithmetica, geometrica, proportioni et proportionalita. Venice.

Pajunen, K. 2006. Stakeholder influences in organizational survival. Journal of Management Studies, 43 (6): 1261-88.

Palmer, D. 1999. Upping the stakes: A response to John Hasnas on the normative viability of the stockholder and stakeholder theories. Business Ethics Quarterly 9 (4): 699-706.

Pesqueux, Y. 2005. Corporate governance and accounting systems: A critical perspective. Critical Perspectives on Accounting, 16 (6): 797-873.

Phillips, K. 2006. American theocracy : The peril and politics of radical religion, oil, and borrowed money in the 21st century. New York: Viking.

Phillips, R. 2003. Stakeholder theory and organizational ethics. San Francisco: Berrett-Kohler.

Phillips, R., Freeman, R. E., \& Wicks, A. 2003. What stakeholder theory is not. Business Ethics Quarterly, 13 (4): 479-502.

Post, J., Preston, L., \& Sachs, S. 2002. Redefining the corporation: Stakeholder management and organizational wealth. Stanford, CA: Stanford University Press.

Romer, P. M. 1986. Increasing returns and long-run growth. Journal of Political Economy, 94 (5):1002-37. 
1990. Endogenous technical change. Journal of Political Economy, 98 (5): S71-S101.

Richards, I. 2004. Stakeholders versus shareholders: Journalism, business, and ethics. Journal of Mass Media Ethics, 19 (2): 119-29.

Rousseau, D. M. 1985. Issues of level in organizational research: Multi-level and crosslevel perspectives. Research in Organizational Behavior, 7: 1-37.

Schneider, M. 2002. A stakeholder model of organizational leadership. Organization Science, 13 (2): 209-20.

Scott, S., \& Lane, V. 2000. A stakeholder approach to organizational identity. Academy of Management Review, 25 (1): 43-62.

Sen, A. 1985. The moral standing of the market. Social Philosophy \& Policy, 2 (2): $1-19$.

1987. On ethics and economics. Oxford: B. Blackwell.

1997. On economic inequality. Oxford: Oxford University Press.

Smith, A. 1776. An inquiry into the nature and causes of the wealth of nations. Dublin: Whitestone.

Smith, H. J. 2003. The shareholders versus stakeholders debate. Sloan Management Review, 44 (4): 85-90.

Stone, A. 1982. Regulation and its alternatives. Washington, DC: Congressional Quarterly Press.

Sundaram, A., \& Inkpen, A. 2004. The corporate objective revisited. Organization Science, 15 (3): 350-63.

Treviño, L. K., \& Weaver, G. R. 1999. The stakeholder research tradition: Converging theorists-not converging theory. Academy of Management Review, 24 (2): 222-27.

Uchetelle, L. 2007. Encouraging more reality in economics. New York Times (January 6), accessed January 6, 2007, at http://www.nytimes.com/2007/01/06/ business/06econ. html?adxnnl=1\&ref=business\&adxnnlx=1168106947-CQ27C $+6 u L l+P p 0 r P S X y M n A$.

Van Buren, H. 2001. If fairness is the problem, is consent the solution? Integrating ISCT and stakeholder theory. Business Ethics Quarterly, 11 (3):481-99.

Velamuri, S. R., \& Venkataraman, S. 2005. Why stakeholder and stockholder theories are not necessarily contradictory: A Knightian insight. Journal of Business Ethics, 61: 249-62.

Venkataraman, S. 2002. Stakeholder value equilibration and the entrepreneurial process. In R. E. Freeman \& S. Venkataraman (Eds.), Ethics and Entrepreneurship (The Ruffin Series No. 3): 45-57. Charlottesville, VA: Society for Business Ethics.

Vickrey, D. W. 1979. General-price-level adjusted historical-costs statements and the ratio scale view. The Accounting Review, 54 (1): 31-40.

Vilanova, L. 2007. Neither shareholder nor stakeholder management: What happens when firms are run for their short-term relevant stakeholder? European Management Journal, 25 (2): 146-62.

Wartick, S. L., \& Cochran, P. L. 1985. The evolution of the corporate social performance model. Academy of Management Review, 10: 758-69. 
Williamson, O. E. 1985. The economic institutions of capitalism. New York: The Free Press.

Wolfe, R. A., \& Putler, D. S. 2002. How tight are the ties that bind stakeholder groups? Organization Science, 13 (1): 64-80.

Wood, D. J. 1991. Corporate social performance revisited. Academy of Management Review, 16: 691-718.

Wood, D. J., \& Logsdon, J. M. 2002. Business citizenship: From individuals to organizations. In R. E. Freeman \& S. Venkataraman (Eds.), Ethics and Entrepreneurship (The Ruffin Series No. 3): 59-94. Charlottesville, VA: Society for Business Ethics.

Wood, D. J., Logsdon, J. M., Lewellyn, P. G., \& Davenport, K. 2006. Global business citizenship: A transformative framework for ethics and sustainable capitalism. Armonk, NY: M. E. Sharpe. 
Copyright of Business Ethics Quarterly is the property of Philosophy Documentation Center and its content may not be copied or emailed to multiple sites or posted to a listserv without the copyright holder's express written permission. However, users may print, download, or email articles for individual use. 